\title{
ПОВНОВАЖЕННЯ ВІЙСЬКОВИХ ПРОКУРОРІВ ЩОДО СКЛАДАННЯ ПРОТОКОЛІВ ПРО ВІЙСЬКОВІ АДМІНІСТРАТИВНІ ПРАВОПОРУШЕННЯ
}

\author{
ПОДОЛЯКА Анатолій Миколайович - доктор юридичних наук, професор, \\ заслужений юрист України, завідувач кафедри теорії держави і права та \\ конституційного права ПрАТ «ВНЗ «Міжрегіональна Академія управління \\ персоналом" \\ ДЬОМІН Юрій Михайлович - доктор юридичних наук, професор, \\ заслужений юрист України, адвокат
}

DOI 10.32782/EP.2021.4.10

Статья посвящена анализу специфбки составления протоколов о военнъх административных правонарушениях военнъими прокурорами, а также выяснению возможности расширения круга субъектов, которим будет предоставлено право составления протоколов о военных административных правонарушениях. Исследуется вопрос создания нового правоохранительного органа - Военной полиции, которая получит право составления протоколов за правонарушения совершеннъе военнъми.

Кроме того, отмечается, что при составлении протоколов об административных правонарушениях военные прокуроры не должны допускать подменъ деятельности военного командования, обеспечивать неотвратимость наказания командиров (начальников), которье не организовъгвли надлежащий уставной порядок в подчиненнъх подразделениях. Подчеркнуто отличие прокурорского надзора от контроля (ведомственного и вневедомственного), а также то, ито военнъе прокуроръ имеют независимъй от командования воинской части, вневедомственнъй статус, дающий им преимущество в объективности и беспристрастности исследования всех обстоятельств правонарушения.

Ключевъе слова: военные прокурорь, военные административные правонарушения, Военная полииия.
Постановка проблеми

Відповідно до статті 131-1 Конституції України в Україні діє прокуратура, яка здійснює представницькі повноваження у передбачених законом випадках [1].

Статус прокурора визначений статтею 15 Закону України «Про прокуратуру» 3 урахуванням спеціалізації органів військової прокуратури.

Згідно з частиною 7 ст. 23 Закону України «Про прокуратуру» під час здійснення представницьких повноважень прокурор у разі встановлення ознак адміністративного правопорушення зобов'язаний здійснити передбачені законом дії щодо порушення відповідного провадження [2].

Стан дослідження проблеми

Окремі аспекти досліджуваної проблематики загалом містяться у працях таких відомих учених, як: В. Б. Авер'янов, О. М. Бандурка, Ю. П. Битяк, В. Т. Білоус, В. В. Богуцький, І. $\curlywedge$. Бородін, Н. П. Бортник, І. П. Голосніченко, О. С. Дніпров, Т. О. Коломоєць, В. К. Колпаков, А. Т. Комзюк, І. М. Коропатнік, О. М. Музичук, В. П. Пєтков, О. П. Рябченко, І. К. Туркевич, О. Ф. Фрицький, Н. П. Христинченко, К. Ф. Шеремет, О. М. Якуба, Х. П. Ярмакі, С. М. Яровий та ін.

Метою цієї статті є розгляд повноважень військових прокурорів щодо скла- 
дання протоколів про військові адміністративні правопорушення.

\section{Виклад основного матеріалу}

Відповідно до пункту 11 частини першої ст. 255 Кодексу України про адміністративні правопорушення (далі - КУпАП) прокурор уповноважений складати протоколи про вчинення військових адміністративних правопорушень, передбачених ст. ст. $172^{10}-172^{20}$ КУПАП.

Порядок провадження у справах про адміністративні правопорушення, у тому числі у справах передбачених «Главою 13-Б» КУПАП, визначається відповідно до цього Кодексу та інших законів України [3, ст.246].

Частиною 1 статті 250 КУпАП передбачено, що прокурор, заступник прокурора, здійснюючи нагляд за додержанням і правильним застосуванням законів при провадженні в справах про адміністративне правопорушення має право: порушувати провадження в справі про адміністративне правопорушення; знайомитися з матеріалами справи; перевіряти законність дій органів (посадових осіб) при провадженні в справі; брати участь у розгляді справи; заявляти клопотання; давати висновки 3 питань, що виникають під час розгляду справи; перевіряти правильність застосування відповідними органами (посадовими особами) заходів впливу за адміністративні правопорушення; вносити подання, оскаржувати постанову і рішення по скарзі в справі про адміністративне правопорушення, а також вчиняти інші передбачені законом дії [3].

3 огляду на відсутність визначення в КУпАП повноважень органу чи посадової особи щодо порядку збирання доказів вчиненого адміністративного правопорушення працівники прокуратури керуються актами чинного законодавства.

Відповідно до ст. 251 КУпАП доказами у справі про адміністративне правопорушення є будь-які фактичні дані, на основі яких у визначеному законом порядку орган (посадова особа) встановлює наявність чи відсутність адміністративного правопорушення, винність цієї особи в його вчи- ненні та інші обставини, що мають значення для правильного вирішення справи. Ці дані встановлюються протоколом про адміністративне правопорушення, поясненнями особи, яка притягається до адміністративної відповідальності, потерпілих, свідків, висновком експерта, речовими доказами, показаннями технічних приладів та технічних засобів, що мають функції фото- і кінозйомки, відеозапису, у тому числі тими, що використовуються особою, яка притягається до адміністративної відповідальності, або свідками, а також працюючими в автоматичному режимі, чи засобів фото- і кінозйомки, відеозапису, у тому числі тими, що використовуються особою, яка притягається до адміністративної відповідальності, або свідками, а також працюючими в автоматичному режимі або в режимі фотозйомки (відеозапису), які використовуються при нагляді за виконанням правил, норм і стандартів, що стосуються забезпечення безпеки дорожнього руху та паркування транспортних засобів, актом огляду та тимчасового затримання транспортного засобу, протоколом про вилучення речей і документів, а також іншими документами.

Обов'язок щодо збирання доказів покладається на осіб, уповноважених на складання протоколів про адміністративні правопорушення, визначених статтею 255 цього Кодексу [3].

Такі дані встановлюються протоколом про адміністративне правопорушення, поясненнями особи, яка притягається до адміністративної відповідальності, потерпілих, свідків, висновком експерта, речовими доказами, показаннями технічних приладів та технічних засобів, що мають функції фото- і кінозйомки, відеозапису, протоколом про вилучення речей і документів, а також іншими документами.

Таким чином, на підставі ст. 23 Закону України «Про прокуратуру», ст. ст. 250, 251, пункту 11 ч.1 ст. 255 КУПАП прокурор збирає докази у справі про військові адміністративні правопорушення для встановлення наявності чи відсутності в діях військовослужбовця складу адміністративного правопорушення та інші об- 


\section{Кримінальне право, кримінальний процес та криміналістика}

ставини, що мають значення для правильного вирішення справи судом.

3 цією метою прокурор має право отримувати пояснення в особи, яка притягається до адміністративної відповідальності, свідків, потерпілих (за їх наявності); отримувати висновки експерта чи довідки відповідного спеціаліста; вилучати встановленим порядком, оглядати та організовувати належне зберігання речових доказів; витребовувати і документувати показання технічних приладів та технічних засобів, що мають функції фото- i кінозйомки, відеозапису; витребовувати необхідні документи, складати протоколи про вилучення та огляд речей і документів; складати протокол про адміністративне правопорушення тощо.

Відомості про наявність підстав для застосування повноважень щодо складання відповідного протоколу про адміністративне правопорушення прокурори отримують 3:

- інформацій, що надходить від органів державної влади, органів місцевого самоврядування, державного нагляду (контролю), правоохоронних органів, органів військового управління, від територіальних підрозділів Військової служби правопорядку, командирів (начальників) військових частин;

- матеріалів кримінальних проваджень, у тому числі закритих;

- матеріалів цивільних, господарських та адміністративних справ;

- Сдиного державного реєстру судових рішень;

- публікацій у засобах масової інформації, мережі Інтернет;

- інформації державних реєстрів, баз даних державних органів, офіційних сайтів державних органів та органів місцевого самоврядування;

- звернень фізичних і юридичних осіб, депутатів усіх рівнів, громадських об'єднань та організацій, а також з інших джерел.

Направляючи запити, прокурор, здійснюючи нагляд за додержанням законів при застосуванні заходів впливу за адміністративні правопорушення, керується ст. ст. 7, 250, 251, 255, КУпАП, ч. 7 ст. 23 Закону України «Про прокуратуру».

За погодженням 3 Головною військовою прокуратурою, керівництвом Збройних Сил України та інших військових формувань рішення, які доведені встановленим порядком до командирів (начальників) військових частин, направляються до органів військової прокуратури (копї̈ протоколів про вчинення підлеглими військовослужбовцями військових адміністративних правопорушень, постанови суду про притягнення до адміністративної відповідальності, копії матеріалів службових розслідувань тощо).

Військовими прокурорами також щомісячні проводяться звірки облікових даних 3 органами управління Військової служби правопорядку у Збройних Силах України та керівниками органів військового управління інших військових формувань про скоєні військові адміністративні правопорушення.

У територіальних підрозділах Військової служби правопорядку періодично отримуються списки військовослужбовців, які відбували адміністративне стягнення у виді арешту з утриманням на гауптвахті, узагальнені облікові дані скоєних військовослужбовцями військових адміністративних правопорушень, відомостей щодо оскарження уповноваженими суб'єктами постанов про адміністративне правопорушення та виконання адміністративних стягнень [4].

Військовими прокурорами також аналізується діяльність керівного складу військових частин, вищих штабів та органів Військової служби правопорядку у забезпеченні неухильного виконання законодавства про адміністративні правопорушення, вжиття заходів щодо усунення виявлених порушень та причин і умов, що їм сприяли.

Під час реалізації військовими прокурорами повноважень особлива увага приділяеться наявності фактів приховування командирами військових частин правопорушень, у тому числі шляхом складання протоколу про вчинення підлеглим військового адміністративного 
правопорушення за умов наявності у його діях складу кримінального правопорушення.

Ретельно опрацьовуються скарги військовослужбовців та членів їх сімей до органів військової прокуратури щодо стану законності у вказаній сфері, звертається увага на наведені у них дані про порушення командирами прав військовослужбовців під час притягнення їх до адміністративної відповідальності (зловживань, перевищень службових повноважень, недбалості, бездіяльності тощо).

На підставі вивчення стану законності військовим прокурорами вживаються передбачені законодавством правові заходи щодо забезпечення невідворотності покарання до правопорушників, а також командирів, які не забезпечили належний статутний порядок у підпорядкованих колективах.

Про здійсненні заходи, проблемні питання та прийняті рішення військові прокурори інформують керівників органів військового управління та військових прокуратур вищого рівня [4].

У військових прокуратурах протоколи про військові адміністративні правопорушення, передбачені статями $172^{10}-172^{20}$ КУпАП, складаються прокурорами, на яких відповідно до розподілу обов'язків керівником прокуратури покладено виконання таких завдань (обов'язків).

Враховуючи, що згідно 3 частиною першою ст. 255 КУпАП протоколи складаються уповноваженою на це особою, до матеріалів провадження у справах про адміністративні правопорушення долучаються документи, що свідчать про те, що прокурор, який склав протокол про військове адміністративне правопорушення, наділений відповідними повноваженнями.

Такими документами можуть бути завірені копії положення про структурний підрозділ апарату військової прокуратури, наказу про затвердження розподілу функціональних обов'язків між працівниками прокуратури або структурного підрозділу апарату, наказу про повноваження конкретного прокурора тощо.
3 метою усунення дублювання під час застосування визначених законодавством повноважень, військові прокурори інформують військове командування про складання протоколів про військові адміністративні правопорушення, вчинені їх підлеглими.

При складанні протоколів про адміністративні правопорушення військовими прокурори не повинні допускати підміни діяльності військового командування, забезпечувати невідворотність покарання командирів (начальників), які не організовували належний статутний порядок у підпорядкованих підрозділах. На це та на відмінність прокурорського нагляду від контролю (відомчого та позавідомчого) неодноразово зверталася увага фахівців адміністративного права [5]. До того ж військові прокурори мають незалежний від командування військової частини, позавідомчий статус, що дає їм перевагу в об'єктивності та неупередженості дослідження всіх обставин правопорушення. в

Протокол про військове адміністративне правопорушення складається 3 дотриманням вимог, встановлених статтею 256 КУпАП.

У разі вчинення військовослужбовцем кількох окремих військових адміністративних правопорушень протоколи складаються щодо кожного правопорушення окремо.

Також у разі вчинення військового адміністративного правопорушення кількома військовослужбовцями протокол про військове адміністративне правопорушення також складається на кожну особу окремо.

Протокол про військове адміністративне правопорушення складається у двох примірниках на спеціальному бланку, один $з$ яких вручається військовослужбовцю, що притягається до адміністративної відповідальності, під його особистий підпис.

Як свідчить судова практика, відсутність у протоколі даних про особу, яка притягається до адміністративної відповідальності, місце її проживання та проходження військової служби стали підстава- 


\section{Кримінальне право, кримінальний процес та криміналістика}

ми для повернення прокурору матеріалів для належного оформлення (постанови Переяслав-Хмельницького місъкрайонного суду Киӥвсъкоӥ області від 21.07.2015 у справі № 373/1808/15n, Суворовсъкого районного суду м. Херсона від 28.08.2015 у справі №668/8992/15n).

У протоколі під час його складання обов'язково зазначається стаття КУпАП та відповідна частина статті КУпАП, згідно 3 якою передбачено адміністративну відповідальність.

Недотримання вимоги про обов'язкове зазначення відповідної частини статті $172^{20}$ КУпАП стала наслідком повернення судом прокурору матеріалів для належного оформлення (постанови Комунарсъкого районного суду Запорізъкої області від 24.06.2015 у справі № 333/4389/15-n ma iнui).

У разі складання протоколу про військове адміністративне правопорушення за частиною 3 ст. $172^{20}$ КУпАП до матеріалів необхідно надавати копії постанов про притягнення упродовж року особи до адміністративної відповідальності за відповідною частиною ст. $172^{20}$ КУпАП (nостанова Мукачівсъкого місъкрайонного суду Закарпатської області від 26.05.2015 у справі № 303/3070/15-n ma інші) [4].

Особлива увага надається повному викладенню у протоколі обставин правопорушення, зазначенню місця та часу його вчинення, суті правопорушення, які саме протиправні дії чи бездіяльність вчинила особа, яка притягається до адміністративної відповідальності, які норми законодавства нею порушено.

Адже закриття судом більшості адміністративних проваджень на підставі п. 1 ч. 1 ст. 247 КУпАП (за відсутністю події і складу адміністративного правопорушення) відбулося $з$ підстав відсутності у протоколі та доданих матеріалах справи конкретних доказів вчиненого особою правопорушення, обсягу іiі службових повноважень 3 підтвердженням їх невиконання, невідображення, у чому саме полягали протиправні дії чи бездіяльність, тощо (постанови Березнівсъкого районного суду Рівненсъкої області від 08.07.2015 у справі
№ 3/555/552/15, Мостисъкого районного суду Аввівсъкої області від 23.09.2015 у справі № 3/448/302/15, та інші) [6].

Прокурор, відповідно до статті 63 Конституції України, зобов’язаний ознайомити особу щодо якої складається протокол про адміністративне правопорушення з їі правами відмовитися від надання пояснень, а також з правами, передбаченими статтею 268 КУпАП, про що робиться відмітка в протоколі [1 ст.63; 3 ст.268].

При складанні протоколу про скоєння військового адміністративного правопорушення обов'язково вказуються всі дані, передбачені статтею 256 КУпАП та дотримуються передбачені законом процедури [3, ст. 256].

Якщо в результаті вчинення адміністративного правопорушення заподіяно матеріальну шкоду, про це також зазначається в протоколі та відповідних довідках - розрахунках, які долучаються до матеріалів протоколу.

До протоколу також долучаються інші матеріали про адміністративне правопорушення: пояснення особи, яка притягається до адміністративної відповідальності, потерпілих, свідків, висновок експерта, речові докази, протокол про вилучення речей і документів, рапорти посадових осіб, а також інші документи та матеріали, що підтверджують факт вчинення адміністративного правопорушення.

Складений протокол та інші матеріали, що підтверджують факт вчинення військового адміністративного правопорушення, протягом трьох робочих днів формуються у справу про адміністративне правопорушення, яка разом із супровідним листом надсилається до районного, районного (міського, міськрайонного) суду за місцем вчинення адміністративного правопорушення[2, ст. 257].

У супровідному листі про передачу справи про військове адміністративне правопорушення до суду зазначаються обставини, суть військового адміністративного правопорушення, клопотання про повідомлення військову прокуратуру про час, місце і дату його розгляду, прийняте 
рішення стосовно переданих матеріалів справи [4].

В останній час активізувалася дискусія щодо створення нового правоохоронного органу - Військової поліції. Поняття «поліція» було предметом наукового дослідження ще до створення цього органу в Україні [7, 8].

Статтею 255 КУпАП передбачено, що органи управління Військової служби правопорядку у Збройних Силах України мають право складати протоколи про правопорушення, вчинені військовослужбовцями, військовозобов'язаними та резервістами під час проходження зборів, а також працівниками Збройних Сил України під час виконання ними службових обов'язків за конкретно переліченими статтями КУпАП. У разі реформування Військової служби правопорядку у Військову поліцію це слід врахувати.

Відповідно до пунктів 11 та 14 частини 1 статті 255 КУпАП у справах про адміністративні правопорушення, що розглядаються органами, зазначеними в статтях 218-221 цього Кодексу, протоколи про правопорушення мають право складати, зокрема:

11) прокурор (статті 172-4 - 172-20; $185-4 ; 185-8 ; 185-11)$ :

14) командири (начальники) військових частин (установ, закладів), командири підрозділів, які уповноважені на те командирами (начальниками) військових частин (установ, закладів) (статті 172-10 172-20) [3, ст. 255].

Правом складання протоколів про адміністративні правопорушення в певних випадках також наділені посадові особи військової інспекції безпеки дорожнього руху військової служби правопорядку у Збройних Силах України, органів Державної прикордонної служби України, органів внутрішніх справ (Національної поліції), органів Служби безпеки України та інших правоохоронних органів [2].

\section{Висновки}

Підсумовуючи викладене вище, можемо констатувати, що право складання протоколів про військові адміністративні правопорушення саме військовими прокурорами, які добре знайомі із законодавством у військовій сфері, до того ж 6 незалежними від командирів військових підрозділів, є дуже важливим.

Водночас, підтримуємо думки фахівців про необхідність прискореного створення такого правоохоронного органу, який, сподіваємося, також зможе посилити боротьбу $з$ військовими адміністративними правопорушеннями, як Військова поліція.

\section{Аітература}

1. Конституція України: прийнята на 5-й сесії Верховної Ради України 28 червня 1996 року. Відомості Верховної Ради Украӥни. 1996. № 30. Ст. 141.

2. Про прокуратуру. Закон України від 14.10.2014 року № 1697-VII. Відомості Верховної Ради Украӥни. 2015. № 2-3. Ст. 12.

3. Кодекс України про адміністративні правопорушення. Відомості Верховної Ради Українсъкой РСР (ВВР). 1984. Додаток до № 51. Ст. 1122.

4. Військові адміністративні правопорушення: Науково-практичний коментар глави 13-Б КУпАП / М.С.Туркот, А.В.Столітній, О.В.Міхед та ін., за ред. М.С.Туркота, 2020, 136 с.

5. Дьомін Ю. М. Прокурорський нагляд в Україні на сучасному етапі: монографія. К.: УкрIHTEI, 2013. 308 с.

6. Судова влада: електронний ресурс: court.gov.ua

7. Міжнародна поліцейська енциклопедія. У 3-х томах. Відповідальні редактори: Римаренко Ю. І., Кондратьєв Я. Ю., Тацій В. Я., Шемшученко Ю. С. Концерн «Видавничий Дім «Ін Юре», Київ, 2005.Т. 2. С. 685-695.

8. Вікіпедія (вільна енциклопедія) (https/uk.wikipedia.org/wiki.) 


\section{Кримінальне право, кримінальний процес та криміналістика}

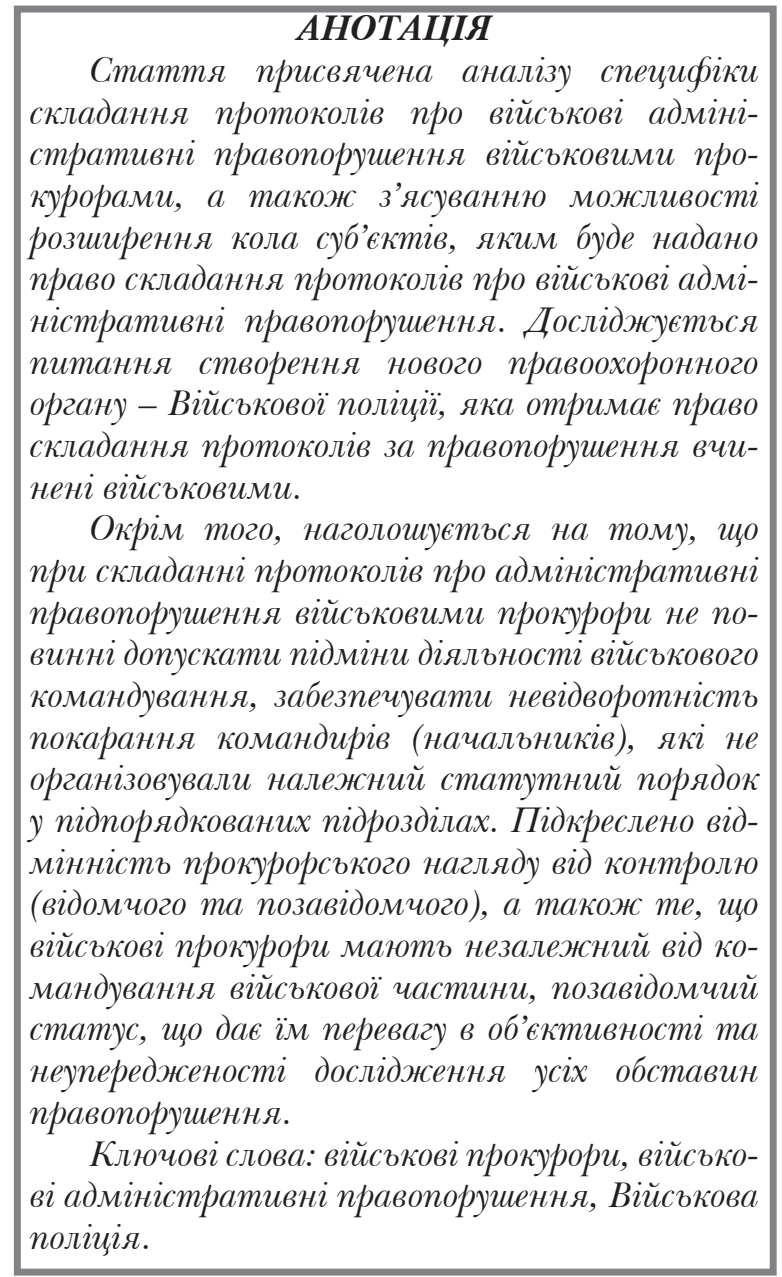

\section{SUMMARY}

The article is devoted to the analysis of the specifics of drawing up reports on military administrative offenses by military prosecutors, as well as to clarify the possibility of expanding the range of entities that will be given the right to draw up reports on military administrative offenses. The issue of creating a new law enforcement body - the Military Police, which will receive the right to draw up reports for offenses committed by the military.

In addition, it is emphasized that when drawing up protocols on administrative offenses, military prosecutors should not allow substitution of military command activities, ensure the inevitability of punishment of commanders (chiefs) who did not organize proper statutory order in subordinate units. The difference between prosecutorial supervision and control (departmental and nondepartmental) is emphasized, as well as the fact that military prosecutors have a non-departmental status independent of military command, which gives them an advantage in objectivity and impartiality in investigating all circumstances of the offense.

Key words: military prosecutors, military administrative offenses, Military police. 